\title{
Antibacterial Activity of thanol Extract and Ethylacetate Fraction of Casia Alata Leaf from Kendari-Southeast Sulawesi
}

\author{
Nurlansi ${ }^{1}$, Jahidin ${ }^{2}$ \\ ${ }^{1)}$ Chemistry Department, Mathematics Education and Sscience - Haluoleo University, \\ Kendari \\ ${ }^{2)}$ Biology Department, Mathematics Education and Sscience - Haluoleo University, \\ Kendari
}

\begin{abstract}
Active compound extracted from Casia alata leaf was obtained from methanol extract and ethylacetat fraction. Based on research, anti bacteria activity of methanol extract of Casia alata at concentration $6 \mathrm{mg} / \mathrm{mL}$ gave high inhibition of the growth of positive gram bacteria colonies of B. cereus and $S$. aureus with inhibition zone $11,0 \mathrm{~mm}$ and $16,1 \mathrm{~mm}$ and gaves negative inhibiton of negative gram bacteria colonies of E. coli and S. typhi with inhibition zone $11,6 \mathrm{~mm}$ dan $5,9 \mathrm{~mm}$. Ethylasetat fraction showed higher zone inhibition then methanol extract. Based on research result it was show that ethylacetat fraction gaves strong inhibition of the growth of positive gram bacteria colonies of $B$. cereus and $S$. aureus with inhibition zone $18,1 \mathrm{~mm}$ and $14,3 \mathrm{~mm}$, and gave moderate inhabitation for negative gram bacteria colonies of coli and S. typhi with inhibition zone $9,0 \mathrm{~mm}$ and $5,7 \mathrm{~mm}$. Separation result of ethylacetat fraction using coloumn chromatography with silica gel $\mathrm{G}_{60} \mathrm{~F}_{254}$ as stationary pahase showed that ethylacetat fraction with the same concentration at $6 \mathrm{mg} / \mathrm{mL}$ show higher inhibition effect especially for positive gram bacteria colonies of $B$. cereus and $S$. aureus with inhibition zone 24,2 $\mathrm{mm}$ and $24.0 \mathrm{~mm}$.
\end{abstract}

Key Word: Casia alata, ethylacetat ftaction, antibacteria activity.

\section{PRELIMINARY}

Ketapang cina Leaf (Cassia alata L.) used by people as traditional medicine to cure skin disease, infected wound, influenza, and bronchitis as well as to cure liver disease. Cassia alata L. is one of local plant from Kendari that interesting to be researched because it has varies chemical constituents. Based on phytochemical screening we found that methanol extracts contained several groups of secondary metabolites such as flavonoids, anthraquinones, alkaloids, saponins and polyphenols. Therefore, exploration of such plants are expected to be useful for the development of science, bioindustry, and other related field in order to empower biodiversity in indonesia

\section{RESEARCH METHODE}

\section{MATERIALS}

INSTRUMENTS

Part of plant that being used was the leaf of Cassia alata. The activity against gram-positive bacteria, of $B$. cereus and $S$. aureus and gram-negative bacteria of E. coli and S. typhi was being tested. Chemical materials that was being use use were petroleum ether, ethanol, nhexane, ethylacetate, silica gel GF254, and reagents for the phytochemicals test.

This research instrument consists of rotary evaporatory coloumn 
chrpmatgraphy electronic balance, ultra violet light, ultra sonic and other tools that commonly used in research laboratorium of organic chemistry

\section{EXTRACTION}

Sample was extracted by graded maceration. Before it put into macerator, simplisia was crude using grinder to enlarge it surface area. Simplicia that has been refined was put into macerator while adding the methanol until all part of simplicia are fully submerged. Submersion was done for 24 hours with three time repetition. Filtrate that was filtered were mix and then evaporate it using rotary evaporator with temperature is $40^{\circ} \mathrm{C}$ until it became viscious extract and after that, extract was weighed. Methanol extract of Casia alata then being partitioned with hexan and distilled water (1:1), water layer that form was taken then being partition using ethylacetat. This ethylacetat fraction of Casia alata leaf than evaporate back using rotary evaporator so crude ethylacetat were obtained.

\section{RESULT AND DISCUSSION}

Antibacterial activity or inhibition activity of methanol extract and fraction ethylacetat of $C$ alata of positive and negative gram bacterial activity is show in table 1.

Based on data at Table 1, methanol extract and ethylacetate fraction of $C$ alata leaf at concentration of $6 \mathrm{mg} / \mathrm{mL}$ show strong inhabition against growth positive gram bacteria of $S$. aureus with inhibition $\mathrm{z}$ one for each are 16,1 dan $14,3 \mathrm{~mm}$. as well as with bacteria B.cereus growth, methanol extract and ethylacetate fraction at concentration of $6 \mathrm{mg} / \mathrm{mL}$ have strong inhabition against growth of positive gram bacteria of.$B$ cereus with inhibition zone for each are 11,0 dan 18,1 mm. At the concentration of $8 \mathrm{mg} / \mathrm{mL}$ both methanol extract and ethylacetate fraction show reduction in effectivity when inhibiting the growth of bacterial colonies. The formation of clear zone for each concentration of material test show that there is inhibition of bacterial colonies reactions because of the effect of anti bacterial compound in material test namely methanol extract and ethylacetate fraction of C. alata leaf.

The nature and strength of antibacterial compounds is determined from the size of inhibition zone against the target bacteria growth. It's based on common standard from health department (1998). According to health department, microbe/bacterial can be categorized as sensitive against bacterial from plant if it has diameter size of inhibition zone between 12-24 mm. According to strength classification of a test substance on inhibition of bacterial colonies as follow: size inhibition zone $\geq 20 \mathrm{~mm}$ as very strong inhibition (2) inhibition zone $\leq 10 \mathrm{~mm}$ until $<20 \mathrm{~mm}$ as strong inhibiton (3) inhibition zone $\leq 5 \mathrm{~mm}$ until $<10 \mathrm{~mm}$ as moderate inhibition (4) and inhibition zone $<5 \mathrm{~mm}$ as weak inhibiton (Aryanti et al., 2007).

Test result of antibacterial activity with methanol extract and ethylacetate fraction of $C$. alata using bacterial gram negative of $E$. coli dan $S$. typhi each show almost no inhibition when compared to two kind bacterial target (bacterial gram positive)

Inhibition of methanol extract of $C$ alata of bacterial bakteri E coli at the same variant concentration of $0,5 \mathrm{mg} / \mathrm{mL}$, $2 \mathrm{mg} / \mathrm{mL}, 4 \mathrm{mg} / \mathrm{mL}, 6 \mathrm{mg} / \mathrm{mL}$, and 8 $\mathrm{mg} / \mathrm{mL}$. each inhibition zone are $4,3 \mathrm{~mm}$; $5,2 \mathrm{~mm} ; 6,5 \mathrm{~mm} ; 11,6 \mathrm{~mm}$ and $8,9 \mathrm{~mm}$. For bacterial $S$ typhi at the same variant concentration of $0,5 \mathrm{mg} / \mathrm{mL}, 2 \mathrm{mg} / \mathrm{mL}, 4$ $\mathrm{mg} / \mathrm{mL}, 6 \mathrm{mg} / \mathrm{mL}$, and $8 \mathrm{mg} / \mathrm{mL}$. show smaller inhibition each inhibition are 0,1 $\mathrm{mm} ; 0,4 \mathrm{~mm} ; 0,9 \mathrm{~mm} ; 5,9 \mathrm{~mm}$ and 2,9 $\mathrm{mm}$. from inhibition zone data we can concluded that methanol extract Cassia alata leaf show inhibition zone moderate to strong inhibiton when inhibiting the growth of E. coli. 
Table 1. The Result of Antibacteria Activity Test of Methanol Extract and Ethylacetate Fraction of $C$. alata Leaf against Bacteria B.cereus and $S$. aureus Positive Gram. and Bacteria E.coli dan S. typhi Negative Gram.

\begin{tabular}{lccccc}
\hline Facteria & $\begin{array}{c}\text { Concentration } \\
(\mathrm{mg} / \mathrm{mL})\end{array}$ & $\begin{array}{c}\text { Methanol } \\
(\mathrm{mm})\end{array}$ & explanation & $\begin{array}{c}\text { Ethylacetate } \\
(\mathrm{mm})\end{array}$ & explanation \\
\hline 1. B. cereus & 0,5 & 4,9 & WI & 5,2 & MI \\
& 2 & 6,3 & MI & 6,3 & MI \\
& 4 & 7,1 & MI & 8,4 & MI \\
& 6 & 11,0 & SI & 18,1 & SI \\
2. S. aureus & 8 & 7,7 & MI & 16,3 & SI \\
& 0,5 & 6,5 & MI & 2,1 & WI \\
& 2 & 7,3 & MI & 3,6 & WI \\
& 4 & 9,0 & MI & 6,2 & MI \\
3. E. coli & 6 & 16,1 & SI & 14,3 & SI \\
& 8 & 10,4 & SI & 8,3 & MI \\
& 0,5 & 4,3 & WI & 1,0 & WI \\
& 2 & 5,2 & WI & 3,3 & WI \\
& 4 & 6,5 & MI & 6,3 & MI \\
& 6 & 11,6 & SI & 9,0 & MI \\
4. S. typhi & 8 & 8,9 & MI & 7,5 & MI \\
& 0,5 & 0,1 & WI & 0,1 & WI \\
& 2 & 0,4 & WI & 3,0 & WI \\
& 4 & 0,9 & WI & 4,2 & WI \\
& 6 & 5,9 & WI & 5,7 & WI \\
& 8 & 2,9 & WI & 4,8 & WI \\
\hline
\end{tabular}

Positive control with diameter inhibition zone $(\mathrm{mm})$ for B.cereus $=24,6$ and $S$. aureus $=$ (tetracyclyn $1 \%$ ) 25,8

positive control with diameter inhibition zone $(\mathrm{mm})$ for B.cereus $=21,1$ and $S$. aureus $=$ (chlorampgenicol 20,63.

$1 \%$ )

Negative control with diameter inhibition zone $(\mathrm{mm})$ for $E$. coli $=$ for $\quad S$. aureus $=0$ B.

(distilled water) $\quad$ Cereus $=0$ dan $S$. thypi $=0$

Explanation:

$\mathrm{M}=$ methanol

$\mathrm{H}=$ Hexane

$\mathrm{E}=$ Ethylacetate

SI = Strong inhabition $\quad \mathrm{MI}=$ Moderate Inhabition (MI) WI= weak Inhibition

Inhibition of ethylacetate fraction of C.alata against $\mathrm{E}$ coli at the same variant concentration of $0,5 \mathrm{mg} / \mathrm{mL}$, $2 \mathrm{mg} / \mathrm{mL}, 4 \mathrm{mg} / \mathrm{mL}, 6 \mathrm{mg} / \mathrm{mL}$, and 8 $\mathrm{mg} / \mathrm{mL}$. each inhibition zone are $1,0 \mathrm{~mm}$; $3,3 \mathrm{~mm} ; 6,3 \mathrm{~mm} ; 9,0 \mathrm{~mm}$ dan $7,5 \mathrm{~mm}$. For bacterial $S$. typhi at the same variang concentration of $0,5 \mathrm{mg} / \mathrm{mL}, 2 \mathrm{mg} / \mathrm{mL}, 4$ $\mathrm{mg} / \mathrm{mL}, 6 \mathrm{mg} / \mathrm{mL}$, and $8 \mathrm{mg} / \mathrm{mL}$. show smaller inhibition each inhibiton are 0,1 $\mathrm{mm} ; 0,4 \mathrm{~mm} ; 3,0 \mathrm{~mm} ; 5,7 \mathrm{~mm}$ dan 4,2 mm. Based on inhibition zone data we can concluded that ethylacetate fraction of Cassia alata leaf, it showed inhibition zone from weak to moderate inhibiton when inhibiting the growth of S. typhi. The formation of a clear zone less than $12 \mathrm{~mm}$ in each concentration of material test show that inhibition bacterial colonies reactions by the effect of anti bacterial compound in ethylacetate fraction did not show significance 
inhibition activity to the growth of target bacterial colonies.

The important things that can be describe here is the inhibition of the growth of bacterial colonies between the fraction of methanol and ethylacetate extracts of $C$. alata leaf mainly on grampositive bacteria that is B.cereus. in table 1 we can see that the inhibition of the growth of bacterial colonies from ethylacetate fraction of C.alata is generally higher than the inhibition of the growth of bacterial colonies from the methanol extract of C.alata at the same concentration of the test substance. This was happening because the active metabolite constituent within $c$. alata leaf become stronger when inhibiting growth of bacterial colonies if it's chemical constituent is in synergy with other chemical constituent.

Separatiom with chromatography column, using silica gel $\mathrm{G}_{60} \quad \mathrm{~F}_{254}$ as stationary phase produce several fraction and after being tested with KLT there are fraction group $\mathrm{EA}_{1}$, $\mathrm{EA}_{2}$ and $\mathrm{EA}_{3}$ (See table 2) where fraction with the highest inhibition is fraction $\mathrm{EA}_{1}$.

Table 2 Antibacterial Test Data Result Using Ethylacetate Fraction of $C$. alata leaf with concentration of $6 \mathrm{mg} / \mathrm{mL}$

\begin{tabular}{cccccc}
\hline \multirow{2}{*}{ Fraction } & \multirow{2}{*}{ Extract weight } & \multicolumn{4}{c}{ Average inhibition zone } \\
\cline { 3 - 6 } & & B.cereus & S. aureus & E. coli & S. thypi \\
\hline $\mathrm{EA}_{1}$ & 2,43 & 24,2 & 24,0 & 12,4 & 10,3 \\
$\mathrm{EA}_{2}$ & 0,95 & 4,0 & 6,7 & 5,1 & 0,0 \\
$\mathrm{EA}_{3}$ & 1,62 & 2,9 & 4,2 & 0,0 & 0,0 \\
\hline
\end{tabular}

Positive control With diameter inhibition zone $(\mathrm{mm})$ for B.cereus $=24,6$

(tetracyclyn $1 \%$ ) and S. aureus $=25,8$

Control positive With diameter inhibition zone $(\mathrm{mm})$ for B.cereus $=21,1$

(chloramphenicol 1\%) and S. aureus $=20,63$.

Negative control With diameter inhibition zone $(\mathrm{mm})$ for $E . c o l i=$ for (aquades) S. aureus $=0$ B. Cereus $=0$ dan $S$. thypi $=0$

without any unsynergic metabolite constituent. According the term of strength of a test substance Aryanti et al.

Table 2 show that test result of anti bacterial activity fraction $\mathrm{EA}_{1}$ with concentration of $6 \mathrm{mg} / \mathrm{mL}$ show higher diameter in inhibition growth of bacterial colonies $B$. cereus and $S$. aureus that is $24,2 \mathrm{~mm}$ and $24,0 \mathrm{~mm}$ compared with original ethylacetate fraction of C. alata leaf is $18,1 \mathrm{~mm}$ and $14,3 \mathrm{~mm}$. This is because, after being separated by chromatography, anti bacterial compound have been separated with other compound so that there would be no mutual interaction that would be weaken for each compound. this show that chemical constituent of C. alata become more active if used in pure compound (2007) fraction $E_{1}$ can be classified as very strong (inhibition zone $\geq 20 \mathrm{~mm}$ as very strong inhibition) against bacteria $S$. aureus and $B$. cereus as well as strong against bacteria E.coli dan S. typhi each are 12,4 and $10,3 \mathrm{~mm}$, while fraction $\mathrm{EA}_{2}$ dan $\mathrm{EA}_{3}$ can be classified as strong to weak against all bacteria target. Based on table 1, ethylacetate fraction can inhibi the growth of bacteria $S$. aureus and B. cereus at strong level and can inhibiting the growth of bacteria E. coli and S. typhi at weak level. The cause of the differences in antibacterial activity of ethylacetate fraction of $C$. alata against positive gram bacterial and negative gram bacterial is 
the differences in component of cell wall. The cell wall of gram positive bacteria $S$. aureus and $B$. cereus is relatively simple, consistis only of three layers: (1) the cytoplasmic membrane, (2) the peptidoglycan layer, and (3) an outer layer called the hoop. While the cell walls of the bacteria $E$. coli and $S$. typhi has layered structure and a very complex cell wall (Jawetz et al., 1986).

\section{CONCLUSION}

Based on this research the conclusions are:

1. Anti bacterial activity of methanol extract $C$. alata leaf show strong inhibition against gram positive bacteria of $S$. aureus and B. cereus and show moderate inhibition against the growth of gram negative bacteria of E. coli and S. typhi.

2. Anti bacterial activity of ethylacetate cassia alata leaf show strong inhibition against gram positive bacteria $S$. aureus, B.cereus and $E$ coli. Also show moderate inhibition against growth of gram negative bacteria namely dan $S$. typhi.

\section{REFFERENCES}

1. Askira M. (2012). Acute Toxicity, Phytochemistry and Antibacterial Activity of Aqueous and Ethanolic Leaf Extracts of Cassia alata Linn. International Research Journal of Pharmacy, vol.3(6): 73-76.

2. Abubacker M.N, Ramanathan R, Senthil K. T. (2008). Invitro Antifungal Activity of Cassia alata Linn Flower Extract. Natural Product Radiance, vol.7(1): 6-9.
3. Breitmaier, E. (1993) Structure Elucidation by NMR in Organic Chemistry. A Practical Guide. John Wiley and Sons.

4. Bojaxa A Rosy Henry Joseph and Rosalie (2010). Phytochemical, Pharmacognostical, Antimicrobial activity of Indigofera aspalathoids vahl. (Fabaceae). International Journal of Biological Tecnologi, vol. 1(1):12-15

5. Harborne, J. B., (1987). Metode Fitokimia: penuntun cara modern menganalisis tumbuhan, cetakan ke 2, penerjemah: Inang Soediro, Penerbit ITB, Bandung. Hlm 13, 14, 15.

6. Kementerian Kesehatan \& Kesejahteraan Sosial RI (2010). Inventaris tanaman obat Indonesia. Jakarta: Balitbang Kesehatan; vol 1 p. 25-66.

7. Khan, M.R., Kihara, M. and Omoloso, A.D. 2001. Antimicrobial activity of Cassia alata. Fitoterapia. 72: 561-564.

8. Kristanty, Roro Inge, Ado (2005). Identifikasi Spesies Malassezia pada Pasien Pitiriasis versikolor dengan Cara Pemeriksaan Morfologi dan Sifat Biokimia di Departemen Ilmu Kesehatan Kulit dan Kelamin Rumah Sakit Cipto angunkusumo Jakarta. Universitas Indonesia. Jakarta,

9. .Luckner M. (1984). Secondary Metabolisme in Microorganisme, Plants and Animals. 4thed., vol. 3, Springer-verlag, Berlin. 